\title{
Giving Mirrors to Female Prisoners in Alice Birch's [BLANK]
}

\author{
Madhawy Abdulaziz Almeshaal \\ English and Literature Dept. College of Arts, King Saud University, Riyadh, KSA \\ Malmeshaal@ksu.edu.sa
}

DOI: http://doi.org/ 10.36892/ijlls.v3i4.766

$\begin{array}{ll}\begin{array}{l}\text { Received: } \\ \text { 17/11/2021 }\end{array} & \text { Abstract } \\ \text { The paper at hand attempts to interpret a contemporary British playwright's } \\ \text { Accepted: } & \text { theatrical artistic attempt to present a disturbing social issue and to suggest } \\ \text { possible modes of help. In [BLANK], Alice Birch confronts the audience with } & \text { the ugly cycle of women's criminal conducts, female criminals' offending and } \\ & \text { reoffending. The playwright employs the theater of the absurd as a theatrical } \\ \text { Keywords: } & \text { medium through which she portrays the absurd reality of these female criminals } \\ \text { Absurd, } & \text { and their families. To confront and shock the audience with the ugliness of these } \\ \text { Criminology, Female } & \text { charterers' reality, Birch uses In-Yer-Face theater. Birch suggests that the } \\ \text { Prisoners, In-Yer- } & \text { female criminal characters are victims who need proper psychological and } \\ \text { Face Theater, } & \text { medical rehabilitation services to break the ugly cycle of reoffending. The } \\ \text { Mirrors, Serotonin } & \text { playwright implies a very challenging question for the audience: is it possible } \\ & \text { to break some patterns of some biological genetic behaviors? That is, can } \\ & \text { female criminals, in [BLANK], break away from their criminal behaviors that } \\ & \text { are biologically innate through the help of medicine and psychology not just } \\ & \text { through some practices of traditional stigmatizing forms of discipline and } \\ & \text { punishment in the justice system that are often proven to be unreliable means } \\ & \text { of constraint? By shocking and confronting society with the ugly reality of many } \\ \text { female prisoners, in [BLANK], Birch is trying to give these pathetic female } & \text { characters'voices, mirrors, selves, forcing society to acknowledge them as } \\ & \text { human beings who have an essential role in society. }\end{array}$

\section{INTRODUCTION}

In [BLANK], written in 2019, Alice Birch presents a universal serious social issue that disturbs most societies: women's criminal conducts. Breaking patterns of criminal behaviors is difficult, almost impossible, not because criminals do not want to or do not try to offend or reoffend, but because doing so might be beyond their human control. In other words, in addition to factors such as adverse childhood experiences, negative social environments, and substance abuse, the biochemical risk factor, Birch proposes, can be an essential factor that contributes a great deal to individuals' criminal behaviors and even to the reoccurrence of these behaviors. In [BLANK], Birch suggests the female criminal characters - mothers, wives, and daughters - are victims who need proper psychological and medical rehabilitation services to break the ugly cycle of reoffending. The playwright implies a remarkably challenging question for the audience: is it possible to break the patterns of some biological or genetic behaviors? That is, can the female criminals in [BLANK] break away from their criminal behaviors that are biologically innate through the help of medicine and psychology and not just through traditional stigmatizing forms of discipline and punishment in the justice system that are often proven to be unreliable means of constraint? 


\section{Giving Mirrors to Female Prisoners in Alice Birch's [BLANK]}

To decode Birch's artistic attempt to theatrically deliver her perspective on the shortcomings of the criminal justice system and on neglected female criminals' cries for help, this study attempts to analyze Birch's use of in-yer-face theater as a medium of the play's theatrical expression. In addition, Birch's employment of different elements of the theater of the absurd to communicate these female characters' intense sense of existential despair created by the absurdity of their conditions is quite intriguing. Moreover, it is essential to analyze Birch's implication of the effects of some biochemical factors, mainly the association between serotonin levels and criminology, which can help societies deal with criminal behaviors when those factors are scientifically identified and psychologically and medically treated.

\section{DISCUSSION AND ANALAYSIS}

The script of $[B L A N K]$ is "a challenge and an invitation . . not only for producing teams but also for the audience" (Sierz, 2001, p. 1). The play is nonconventional and challenging, like "a jigsaw puzzle with several pieces missing" (Billington, 2018, p. 1). It is 440 pages long and comprises 100 separate, self-contained scenes: 50 scenes to be performed by adults and 50 scenes to be performed by children. [BLANK] is not a conventional play with a plot or characters development. Though extremely challenging, this "build-your-own-play approach ends up giving us slivers of information rather than a coherent whole" (Aberg, 2019, p. 1). The scenes are titled and can be viewed as separate or connected since they center on abused, vulnerable, neglected women in need of serious help rather than legal discipline and social punishment. Most of these characters are females of all ages who are affected by the criminal justice system. These nameless female characters are grandmothers, mothers, daughters, sisters, guards, and social workers who feel smothered by different circumstances, their families, their friends, and the state. The reoccurring themes are related to the "cyclical nature of abuse and the inadequacy of penal institutions in dealing with the root causes of criminality" (Aberg, 2019, p. 2).

Since the origin of theater, the effectiveness of a play, especially a tragedy, has been judged based mostly on its Aristotelian cathartic effect, the level of the audience's sense of fear and awe. Overtime, different playwrights have experimented with different theatrical performances to intensify this cathartic sense when delivering a theatrical piece to the audience. One of these experimental forms that Birch employs in [BLANK] as a medium to illustrate her perspective on women and the criminal justice system is in-yer-face Theater. In-yer-face Theater is a provocative confrontational British theater that became popular in the 1990s. It is defined by New Oxford Dictionary as a theater that is "blatantly aggressive or provocative, impossible to ignore or avoid." In-yer-face theater is a contemporary British drama form that many playwrights use to "break with conventional theatrical codes to confront the vulgar and the shocking" (Sierz, 2001, p. 1). It is the type of theater that "confronts, surprises, and disturbs to grab the audience by the scruff of the neck and shakes it until it gets the message" (Sierz, 2001, p. 1). In-yer-face theater has been described as an experiential theater that "aims to give the audience the experience of actually having lived through the actions depicted on stage ... it grabs its audience and forces them to confront the reality of the feelings shown to them" (Sierz, 2001, p. 2). Though its language and actions lack decorum, In-yer-face Theater has a distinctive voice and an exciting form. Birch uses this type of theater to represent many female characters in $[B L A N K]$ as victims of criminology who deserve recognition as an essential part of society: "If we do not represent them, then we are in danger of denying their existence" (Rebellato, 2017, p. 178). 
"The interest in victimology as a science has been established since 1947 and currently is not limited to the justice system, but it has intrigued who is ever interested in preserving and advocating human rights" ("Introduction to Victimology", 2018, p. 1). Victimology, a branch of criminology, is "the study of etiology (or causes) of victimology, its consequences, how the criminal justice system accommodates and assists victims" ("Introduction to Victimology", 2018 , p. 1). Victimology is a science in which scientists "use the scientific method to answer questions about victims" ("Introduction to Victimology", 2018, p. 1). Like most victimologists, Birch attempts to question the different possible causes of victimization of many female criminal characters in [Blank] through different theatrical means. The playwright's employment of different aspects of the theater of the absurd as a way to convey these female characters' inabilities to cope with their social, financial, and psychological conditions is provocative. Albert Camus' The Myth of Sisyphus best explains the philosophy of the absurd: it is an existential outcry of the absurdity of the human condition. Camus compares man's life on Earth to the labors of Sisyphus. Sisyphus was condemned by the gods to roll a rock up a mountain slope. When it reached the top, it rolled down again, and Sisyphus would have to push the rock back up only to have it roll down again: "The world is an existential nightmare from which reason, forgiveness and hope are absent" (Hinchliffe, 2019, p. 6). Theater of the absurd dramatists believe that just as life is meaningless, so is language, because it is no longer able to serve as a medium of communication between human beings. Language becomes a method of concealing rather than revealing one's thoughts (Esslin, 2001, p. 91). The themes in the plays of the theatre of the absurd evoke the "sense of metaphysical anguish at the absurdity of the human condition" and provide a "sense of the senselessness of the human condition and the inadequacy of the rational approach" (xix). Dramatists strive to express this senselessness by openly abandoning "rational devices and discursive thought" (xx).

In [Blank], the absurdity of the female criminal characters' conditions is obvious from the intriguing title of the play. The word blank inside square brackets suggests what is not spoken: an afterthought, digression, aside, or statement that is left for the audience's own speculation that they soon realize the play needs more than it needs words in the title. In addition, all of the letters of the scene titles are capitalized. Though that can be interpreted as a theater of the absurd characteristics or possibly as the playwright's intention to draw some production instructions in the script, one cannot overlook the fact that "capitalization is commonly used to denote importance or distinction" (Shelly, 2020, p. 1). The play is dreamlike with the nameless characters, both adults and children, stuck in a grotesque, violent past and a hopeless present as they wait for the unknown. All these characters talk about is desertion, imprisonment, addiction, domestic violence, mental illness, infanticide, fear, guilt, and depression. The audience feels exhausted from trying to make sense of the nonsense with different attempts to apply a definite setting of time and place, identify characters, order scenes, and form a possible plot by drawing some relationships between two or three scenes. Through this sense of everlasting exhaustion, the audience is able to grasp Birch's talent in conveying the difficult circumstances these female characters and their children are struggling to survive. Frequent references to Birch's work concern its meticulousness regardless of the medium in which she works and the richness of her poetic and vivid dialogues. The balance between witty humor and frightening tensions forms part of her identity. With a family background in psychoanalysis, she draws on its methods to understand people who will become her characters. 
"I work until I know that I could put them into any situation and know their responses as well as I know my own," Birch says (qtd. in Hoggard, 2017, para. 2).

Though Birch focuses on these female criminals' miserable circumstances, she confronts society as a responsible agent for these mothers' and daughters' patterns of agonizing realities. That is, "women sentenced to prison . . usually serve short sentences for non-violent offences. These sentences disrupt the lives of women and their families and typically women don't have access to rehabilitation services to help break the cycle of reoffending" (Ambrogi, 2019, p. 1). This fragmented vision "disrupts the assuredness of language, the unity of meaning, and the clarity of expression" (Sierz, 2001, p. 54). Throughout the 100 scenes, the audience feels confronted and disturbed by the different characters' appalling sense of despair and their apocalyptic visions of life. Almost all of the female characters - mothers and daughters - are deeply depressed, helpless, and hopeless. For instance, in the scene, GRANDKIDS, a young mother begs her mother for help and support by taking care of her three young children so she can sleep a few hours, but the mother refuses (Birch, 2017, p. 232). In the next scene, REFUGEE, the young mother locks her kids in the car and begs for a safe place to keep them because someone is after their father and has threatened to kill them, but she is denied a safe shelter because "there is no space, no extra beds" for them (Birch, 2017, p. 251). Soon after, in LESSON, the kids are violently killed by their mother. In BLOSSOM, the mother, a depressed drug addict, is being interviewed by a mental health representative and confirms that she has been depressed and tired and has been hearing "voices and whispers for weeks" (Birch, 2017, p. 287). Though the mother can hardly recall much, she soon remembers "the bath of blood" and admits, "it must have been me" (Birch, 2017, p. 289). She could not take care of them because she was "exhausted, couldn't cope, sad, and they were loud that [she] couldn't figure out how to care for them. . . it was like putting on the wrong clothes on or getting lost Constantly," so she killed them "out of pity" and in "sparing them life," "[e]nding their suffering. Stopping the potential of any more pain" (Birch, 2017, p. 293). The painful reality that infuriates the audience, in ALCOHOL, is that the social worker knew about the mother's depression and drug addiction two hours before the kids were killed yet did not help simply because he was drunk. When confronted later, he confesses that the mother begged him to take her kids for some time, but he did not because he was "unsupported, resourced, unstaffed" (Birch, 2017, p. 305). In VICTORIA SPONGE, another mother, waiting to go to prison, begs her neighbor to "be kind, support, and love" her kids: "My children haven't done anything wrong . . . [they] could use some support and friendship. And Love. Some of that Love. Fiercely. I'm not asking for me" (Birch, 2017, p. 53). With such scenes, the audience is held by the scruff of the neck when they are confronted with the absurd realities of these mothers and their families.

Birch succeeds in confronting and disturbing the audience, so they are ready for the play's message. Birch's message that the audience struggles to discern throughout the play has been summed up in how to help not just as a part of one's social responsibility but out of a universal human responsibility. As in most of her plays, in [BLANK], Birch advocates a means of support that societies' health care officials and legal scholars can employ to save a group of desperate individuals and generations, which is exploring means of help other than traditional ways of legal discipline, mainly imprisonment. Birch proposes the necessity of exploring a possible relationship between criminal behaviors and human biology: "I'm interested in whether trauma can be passed on through DNA . . what is passed into families and what is 
inherited" (in Jones, 2020, p. 8). In other words, Birch suggests that there are some biological factors beyond human control that if moderated can improve the quality of life of many victims similar to the female criminals in [BLANK].

Like many recent studies, Birch adopts the idea of a possible correlative relationship between human biology and aggression. To elaborate, in "Biosocial Criminology and Modern Crime Prevention," Rocque, et al (2012) seem to sum up Birch's point of view regarding "targeting the psychosocial half of the biosocial equation [that] appears to be the most effective strategy to prevent crime from a biological perspective" (Birch, 2017, p. 308). Like Birch, researchers in a variety of fields are arguing, "[B]iology should play a role in prevention as well as treatment of criminal behavior" (Birch, 2017, p. 308). Interestingly, Allan Siegel and John Douard pose an essential question that might sum up Birch's argument: "To what extent can we hold violent criminal offenders responsible for their conduct if that conduct is the result of deterministic biochemical processes in the brain?" (Birch, 2017, p. 20). They add, "[L]ow brain serotonin levels induce impulsive aggression which overrides mechanisms related to rational decision-making processes" (Birch, 2017, p. 20). They further explain the role of serotonin in the brain:

Serotonin does not cross the blood-brain barrier. Therefore, brain serotonin results from the synthesis in selective brain cells situated in the raphe nuclei of the medulla, pons, and midbrain. The substrate for serotonin formation is dietary tryptophan, which enters the brain through an uptake process. In brainstem raphe neurons, it is hydroxylated to form 5-hydroxytryptophan by tryptophan hydroxylase. It is then decarboxylated to form serotonin by aromatic-L-amino aciddecarboxylase and stored in vesicles and ultimately released on to neurons with which it makes synaptic contact. The mechanism for removal of serotonin from the synaptic cleft is by reuptake and metabolism. Serotonin is deaminated to 5-hydroxyindoleacetaldehydeby monoamine oxidase and is then oxidized to form 5-hydroxyindolaceticacid by aldehyde dehydrogenase and ultimately secreted through the urine. (Birch, 2017, p. 21)

Based on the above description of serotonin synthesis, it should be readily seen that studies could be designed to determine the effects of serotonin and violent behavior through modification of brain levels of serotonin by: (1) altering dietary levels of serotonin, (2) controlling enzyme synthesis, (3) serotonin receptor activation or blockade, (4) inhibiting reuptake of serotonin, and (5) genetic manipulation of serotonin and its receptors. In addition, the effects of serotonin upon violent behavior could also be discerned by correlating brain levels of serotonin in individuals with their propensity to express aggression and rage (or other forms of violent) behavior. (Siegel \& Douard, 2011, p. 12)

Siegel and Douard conclude,

There may well be individuals who, for example, have very low levels of brain serotonin (and possibly abnormal levels of other neurotransmitters that regulate aggressive behavior) which, for unknown reasons, are resistant to pharmacological treatment, psychotherapy, and other behavioral conditioning procedures. Such individuals may not have the degree of guidance control to warrant attribution of responsibility and culpability. They may more closely resemble the Parkinson patient who suffers from a hypokinetic disorder. Therefore, in evaluating the behavior of an individual in terms of assessing whether he is responsible for his actions, the extent to 
which an individual is capable of consciously deciding not to perform an inappropriate act must be factored into the category in which he is placed, and the appropriate response of the criminal justice system. (Siegel \& Douard, 2011, p. 28).

Thus, based on many scientific studies on the relationship between serotonin and criminology concluding that "[1]ower serotonin metabolite levels appear to be a marker for general antisocial behavior" (Wilson \& Scarpa, 2012, p. 13), one can grasp Birch's implied argument that effective means are available that if taken into consideration by legal authorities can help break or reduce the cycle of offending and reoffending in society and help save women and their families. That is, "[c]riminologists should strive to create an integrative model of criminology that addresses both the traditional sociobiological factors in addition to biological factors" (Wilson \& Scarpa, 2012, p. 14).

To understand the correlation between the effect of brain serotonin and aggression, one must not overlook the relationship between serotonin and depression since depression is a key issue related to aggression:

Etiologically, depression is a neurobiological disorder associated with derangements in neuro-chemical, neuroendocrine and neuro-immunological functions. The possibility that peripheral abnormalities in serotonin metabolism occur in melancholic patients has been investigated by the study of serotonin content of various body fluids including cerebrospinal fluid (CSF), plasma and platelets. Studies have shown that free serotonin is greatly raised in stressed mammals. The concentration of synaptic serotonin is controlled directly by its reuptake into the pre-synaptic terminal; therefore, drugs blocking serotonin transport have been successfully used for the treatment of depression. The mode of action of these antidepressant drugs on their direct target, the serotonin transport protein and possible regulatory mechanisms in alleviation of depression. (Saldanha et al., 2009, p. 3).

The mental and mood disorders that most of the female characters in [Blank] experience are striking. By portraying these characters' pathetic psychological conditions, Birch forces the audience to think about causes of these characters' depression other than their environmental and social circumstances. In other words, these female characters' difficult social and financial circumstances inside and outside prison are obvious. These characters' weak family structures are haunting. Almost all fathers are absent, and mothers are often imprisoned. Many children are born in prison and separated from their mothers after eighteen months, and sometimes a prison is closed, and many mothers are moved to other prisons that are not close enough for their children to visit. Moreover, in FAS, the audience is confronted with the truly disturbing fact that many newborn babies of imprisoned mothers are diagnosed with fetal alcohol syndrome and are expected to have movement and coordination problems; learning difficulties; problems with thinking, speech, social skills, memory, etc.; problems with their liver and kidneys; and growth problems (Birch, 2017, p. 209).

When or if they are present in their children's lives, most of these mothers are often depressed, drunk, or violent, which is a devastating reality that causes these characters', mothers', and daughters' deep depression and high rates of reoffending and often triggers the desire to commit suicide to escape their difficult pasts and presents. One of the devastating situations for two children, in TWEEZERS, is trying to get their drunk mother out of bed so she does not lose her job, where she has scheduled meetings. They try different means such as poking her with a sharp pencil, using a hairdryer on her arms, tweezing some of the hair on her 
big toe, flicking her ankles, twanging her forehead with an elastic band, lighting matches near her fingers, and throwing a cabbage, a shoe, and the cat at her forehead as desperate measures to save their family: "She's going to get sacked. And then she'll be miserable. And she'll drink more. Except there'll be no sorry's or Attempts to get better. And there'll be no money. And we'll be f. .." (Birch, 2017, p. 123). Moreover, an example of a pathetic mother is A's mother, in HOME BIRD, who is described as "really fun" because "she's the one letting us [children] drink or giving fags or telling us how to kiss boys or cheat in exams and that [we] shouldn't worry about next week or tomorrows or next years cos Now is here" (Birch, 2017, p. 21).

Related to being present in their children's lives, most of the mothers are hopeless and pathetic. In RYEVITA, B's mother is absent and her kids are terrified. B tells A,

It is all gone . . . The $f$...food the $f \ldots$ water the $f \ldots$ electricity has all $f \ldots$ gone and she [the mother] has gone. She has gone she has Definitely gone this time and you were gone you were gone for three days and I was Scared I was Properly Scared . . There is literally nothing left in the fridge or round the back of the cupboards or in the freezer or round the back of the freezer or under the floorboards or in the gardenthere is nothing in the garden-... she has never been gone this long before. (Birch, 2017, p. 5)

In TAPE, two kids get into an ugly fight, and one stabs the other out of jealously simply because her mother is dead: “I'm joking. I'm just pissing around. I'm just jealous. Envious. My mother is dead. Stone cold dead. It's great yours is sending you stuff. That's really nice. That's just brilliant ... Can I have a look? ... I've not seen a letter in a long time. On account of my mother being deceased and all" (Birch, 2017, p. 33). Shortly thereafter, B starts spooling the tape that A's mother has sent. One cannot help but apply the concept of the dead mother complex when analyzing Birch's female characters' haunting pasts and everlasting presents that are worsened by these female characters' troubled relationships with their mothers and/or their own children.

The dead mother complex concept can help the audience understand most of Birch's troubled feelings about most daughters and mothers:

The dead mother complex is a phenomenon expressing the sudden anticathexis of the child by the mother. Confronted by the meaninglessness of this anticathexis, the child is forced to structure around a void that, even if it doesn't prevent him from forming links with objects and people, does make said links shallow. The subject enters into a sort of wandering, repeating outside that original link with their own mother, running away in moments which demand them to look deep into themselves. (Green, 1993, p. 21)

Being separated from a nurturing mother or living with an abrasive mother who cannot take care of herself or her own children has a devastating effect on the female characters' wellbeing in $[B L A N K]$. Most have "physic holes" or "White Depression" because of this complex. (Green, 1993, p. 22). Most of the female characters in [BLANK] could be diagnosed as having melancholic depression, which is a severe stage of illness that severely affects people such that they lose interest in almost everything around them including life itself ("Types of Depression"). For example, in RESTAURANT, an inmate has killed herself, and the sad thing in this scene is that she has repeatedly asked for help, but no one helped. In RESTRAIN, an inmate has been suffocated and cannot breathe because she has been violently retrained so she does not hurt herself. In CODES, there is a terrifying report from only one evening about 
different cases of attempted suicide inside a female prison using different means such as razor blades, ligatures, and plastic bags.

Moreover, in QUEUE, after confirming that she could electrocute herself with the TV, a glass, a razor, and the table leg, depressed B asks for the television to be taken away so she does not harm herself when she is alone. She asserts that she needs someone to "restructure" her heart and "rewire" her brain so that

everything doesn't look like a way to get out - because right Now, this minuteEverything, every Single object seems to be uncurling itself, unfolding itself and revealing its potential to do me harm. To lead me out — not gently — not painlesslynot Kindly or Simply - I do Understand that if I were to press this table leg through my throat or my skull or my heart it would hurt and I would Bleed and it would be slow but it would be out. Eventually. It would be a Way out. It would be an End. It would be a Climbing out of what is nearly, barely a life and it would be a Finish. A Finish. (Birch, 2017, p. 159)

These female characters' melancholic depression and their loss of interest in life is reflected in their different suicide attempts.

Although the high sense of existential despair among Birch's female characters has many obvious social and familial causes, the playwright draws our attention to a biochemical factor: a lack of serotonin in the human brain, which contributes a great deal to these characters' depression and high sense of despair. According to many studies, "the pathogenesis of endogenous depression is connected chiefly with a disturbance in the biosynthesis of serotonin - that is to say, with reduced serotonin levels in the brain" (Kielholz, 1972, p. 279). Some established theories indicate that depression could be caused by the depletion of certain neurotransmitter substances in the brain. Brain cells use neurotransmitters to send signals to each other (Schimelpfening, 2019, p. 6). Those with depression suffer from a chronic state of melancholy, an intense mental pain, a lack of interest in life and the world, and a tendency to see their condition as inescapable (Barbagli, 2015, p. 10). Neurotransmitters, serotonin, norepinephrine, and dopamine are involved with the origins of mood disorders. For example, depression is caused by severe depletions of serotonin, dopamine, and norepinephrine in the brain. Serotonin, in particular, is deeply implicated in the roots of depression, sleep regulation, aggression, and suicide. One might argue that most of the depression among these female characters can be associated with "the menstrual cycle, pregnancy, childbirth, and menopause that can all contribute to depression in women" (Schimelpfening, 2019, p. 11).Yet, for these criminal female characters, it is more than natural feminine depression and beyond the menstrual cycle. Studies have shown that depression reflects an interaction between environmental and genetic factors. Research has also demonstrated that an interplay of biological, genetic, and epigenetic factors contribute to depression (Kim, 2018, p. 36). Some studies have investigated the biological side of mental processes by examining endorphins, psychoactive receptor sites in the brain, pituitary-hypothalamic function, and the neuroanatomical pathways that mediate mood and behavior. These areas of investigation enrich the understanding of mind-brain relationships (Bassuk et al., 1982, p. 9). For example, in [BLANK], most of the female prisoners are chronically depressed and do not seem to be able to grow out of their high sense of depression, to the point that they are at danger of committing suicide. 
Closely related to most of the female characters' sense of depression in [BLANK] is their high sense of guilt about themselves and their families:

Guilt is aversive and-like shame, embarrassment, or pride-has been described as a self-conscious emotion, involving reflection on oneself. People may feel guilty for a variety of reasons, including acts they have committed (or think that they committed), a failure to do something they should have done, or thoughts that they think are morally wrong. (Perina, 2012, p. 1)

Excessive guilt can be a feature of certain forms of mental illness, including depression and posttraumatic stress disorder. The tendency to feel shame has also been associated with depression, anxiety, and other psychological symptoms. Most of the female criminals throughout the play have an overwhelming sense of guilt, especially the mothers. In DRAWING, A visits B's mother in prison. A tells B about how her mother feels about her and gives her a drawing of her as a baby at the beach, even though B's mother never got to take her. A concludes the long message from B's mother with some guilty remarks, as a way to assure her daughter of her love:

And that she was a shit Mum. And that she wished she'd just taken you to the beach on a hot day like a Normal Mum. Like Mums are supposed to. And that she draws you. All the time. Cos she's got no pictures of you. She said her wall is covered in pictures of us cos Gran had us and sent pictures but with you no one had you so no one took pictures so there are no pictures to send so she draws you. And that she's so sorry. And that she did kiss you ... .she did watch ... she did feel close to you, she did feel your Closeness and you Smallness ... and she did feel— just for a little bit—like a Mum to you but that you deserved to have an Actual Mum all the time and so she draws you ... (Birch, 2017, p. xx)

She adds, "[S]he cried the whole time" (Birch, 2017, p. 201). B replies, "Did you tell her I hated her?" and asks A, when A visits B's mother next time, to tell her, "I wish she'd drank herself to death before bothering to have kids" (Birch, 2017, p. 201). In RECORD, A, an imprisoned mother, describes her daughter, B, as upset, sad, and devastated. She records a tape for her young daughter apologizing for caring about drugs more than her own daughter until the daughter ended up in prison too:

She's devastated. I've completely devastated her. She's so small and I've managed to ripher up. It is like I've declared war on her little bones. She's War Torn. Famine and f . . . wreckage, I've wrecked her cities and bombed her land and her seas and her skies. I have detonated them. I have caused a Nuclear explosion inside her. She's F . . Chernobyl. That thing I held. That Bundle. That Squashed pile of limbs and features and Creams and Shit that I was supposed to grow as best I could — I f . . ruined her. (Birch, 2017, p. 27).

She adds, "I Managed somehow not to kill her inside me, Birthed her in a Haze of Drugs and Pain and Misery and then ignored her for two years till I ended up here" (Birch, 2017, p. 31). She concludes, "So maybe there is nothing to salvage. So maybe there's nothing to save. So maybe I'm done. Maybe I'm probably done" (Birch, 2017, p. 31). These female criminals' constant sense of excessive guilt is exhausting for the audience to follow, which is part of Birch's use of in-yer-face theater's confrontational function.

Despite the absurdity and sense of despair experienced by Birch's female characters in [BLANK] due to their difficult circumstances, Birch's optimistic constructive touch 
distinguishes her reformative talent as a playwright. Throughout the play, Birch reminds the audience that these female characters are human beings who deserve a chance to live a better life. As Ambrogi confirms, "[W]ith [BLANK], Birch ultimately questions the way we, as society judge women in general and the consequence of being defined by the experience of prison" (Birch, 2017, p. 1). Ambrogi adds, as Margret Atwood wrote in her poem "Marrying the Hagman," "To live in prison is to live without mirrors. To live without mirrors is to live without the self" (Ambrogi, 2019, p. 1). Ambrogi concludes, "[Blank] is a heartfelt attempt to give back shards of those mirrors and dignity to women involved with the criminal justice" (Ambrogi, 2019, p. 1). To adopt Atwood's concept of a mirror as a self, one can grasp Birch's emphasis in [Blank] on these female criminals' sense of identity and human rights as an essential part of society that must be acknowledged fully, instead of being marginalized and alienated because of some offences they committed without having access to rehabilitation centers to help them break the ugly cycle of reoffending. By using a confrontational mode- $\mathrm{a}$ theater of the absurd - through a disturbing theatrical representation-in-yer-face theaterBirch give mirrors, selves, and voices to the silent, pathetic female characters in [BLANK]. She even holds a mirror to society itself by giving a loud, nonverbal cry for help that communicates these voiceless characters' helpless reality. This forces the audience-society-to reflect on possible ways that might help not just female criminals and the justice system but society as a whole.

In Mirror: A History of the Human Love Affair with Reflection, Pendergrast writes, "A history of the mirror is really the history of looking, and what we perceive in these magical surfaces can tell us a great deal about ourselves-whence we have come, what we imagine, how we think, and what we yearn for. The mirror appears throughout the human drama as a means of self-knowledge or self-delusion" (ix). Moreover, Levine asserts, "self-knowledge obtained through self-reflection, whether assisted, observed, or self-mediated, serves as an important scaffold on which experience and sense of self are integrated or constructed and gives continuity, coherence, and meaning to life" (305). Most critics argue that "understanding the concept of reflection is perhaps the first step in the use of this process for self-awareness" (La Torre, 2005, p. 85). The mirror metaphors in Shakespeare's plays sum up his "concern with identity, illusion, and reality" (Pendergrast, 2003, p. 125).In other words, the mirror, "a tool by which to 'know thyself,' invited man to not mistake himself for God, to avoid pride by knowing his limits, and to improve himself. His was thus not a passive mirror of imitation but an active mirror of transformation" (Melchior-Bonnet, 2001, p. 106). Thus, a mirror is an essential metaphor that reflects one's desire to reach a sense of self-knowledge and to experience a transformational stage in the process of one's self-awareness. To have a mirror, these women in the play must acknowledge themselves as human beings to be able to deal with their absurd reality.

In his discussion of the mirror stage, Jacques Lacan stresses the human nature of the mirror stage throughout our lives as we "constantly strive for the ideal" (Lacan, 1949, p. 78).If having a mirror is a step towards striving for an ideal self, then Birch's female prisoners in [Blank] need mirrors to fulfill a human desire for narcissism and to create images of a perfect self and world. Narcissism refers to self-love, vanity, egotism, and selfishness, according to Freud (Lacan, 1949, p. 160). An initial step that these female prisoners need as human beings is to have mirrors - selves - to be able to love themselves as individuals and not just as caretakers. The play has many references to magnolia trees, which can be interpreted as 
symbolic representations of a woman. Although it is a short-lived tree that blossoms for only two weeks, a magnolia tree symbolically represents endurance, resistance, strength, purity, dignity, depth, and originality ("The Incredible Symbolism"), making it an implied symbol of a woman's essential role in society. In ARMS, a mother declares that she is "a whole human being . . . not just a mother. ... [She] would like an existence outside of being just a Mother" (Birch, 2017, p. 23). BODIES has a strong emphasis on the idea that a woman should value herself by appreciating and loving her body as a component of herself as an individual. In a prison cell, A confirms that she likes

women who Like their bodies - not what they can do, not what their body is capable of Doing, but the body Itself Not that Maternal Motherhood Shit, those Womanly words about being a Home or a Vessel or a space for something new, birthing or feeding, isn't it remarkable that my body can sustain a human being . . . I'm not talking about a a a profound connection to the earth, rooted through your biologythrough your Tubes and your Ovaries. (Birch, 2017, p. 147)

A discusses a woman's body as part of her individuality as a human being, rather than as a mother only. To Birch, giving the female criminal characters in [BLANK] mirrors allows them to live with themselves and gives them a voice by acknowledging them as a very essential part of society, by releasing them from stereotypical patterns through empathy and sympathy. Depicting these characters as human beings who need means of support other than harsh traditional forms of legal discipline will help to reduce their chances of reoffending and help them to contain themselves as human beings so that they can care for their families and offspring. Considering the biochemical factors that might have forced many to serve prison time can help societies to look at these women as victims of their own biological chemical hormones, in addition to their difficult circumstances. Although it is confrontational, the play stimulates the audience' cathartic attitude, pity, and fear.

The last scene of the play, DINNER PARTY, takes place in "a very liberal, Twittertype bubble" (Aberg, 2019, p. 2) where twelve different female characters talk about types of food and different cuisines, political reform, global women movements, filmmaking, and many other issues. The scene, a banquet scene, starts with different cuisines, ethnic dishes, and kinds of wine and even cocaine, which is delivered by bicycle. The characters in this scene are not victims; they include a police officer, an architect, a therapist, and a head teacher. There is a reference to the $2006 \mathrm{Me}$ Too movement aimed at "stopping the silence" against violence and supporting marginalized people in marginalized communities. The Me Too movement started to stop the silence against sexual harassment and was an attempt to empower the marginalized through empathy, especially with young, vulnerable women. Birch alludes to this movement as a way to question the audience's awareness of these female characters' difficult situation and society's role in helping them to improve their conditions through thinking of different means of support. In the banquet scene, Birch "turns the table on the audience and questions whether the concern of principled middle-class people for women involved with the justice is genuine" (Ambrogi, 2019, p. 1). This last scene is more of a mirror scene that "exposes the superficiality of these friends' concerns for women's rights and poverty and highlights how the way they live might in some ways contribute to perpetuating inequalities" (Ambrogi, 2019, p. 1). At the end of this last concluding scene, the playwright confronts society by having a young girl stands on a chair and smash up the dinner table with a baseball bat. Through this little girl's violent act, Birch again holds the audience by the scruff of the neck and forces them to reflect 
on possible ways to help these marginalized female characters and their families. The play is concluded with the question of in-yer-face theater: "How can change ever be achieved if we do not accept that people should be held responsible for their actions?" (Billington, 2018, p. 1). Birch wishes that "hopefully there is one audience member who feels changed in a personal way, but it is a much longer process" (qtd in Jones, 2020, p. 3).

Similar to trying to give mirrors to female criminals, in [BLANK], Birch holds a mirror to society, in an attempt to make a difference and provoke social responsibility and a desire for change. For instance, in ICE, A summarizes social hypocrisy when it comes to social responsibility when they and their friends came across a bleeding man in front of C's house and nobody bothers to even call an ambulance:

I'm just saying that we should all be $\mathrm{f}$. . . honest about the fact that getting involved in that kind of shit - that kind of shit that happens All The Time to people Nothing like us - is no good is bullshit is nothing I'm interested in. I give to charity. I pay more than my fair $\mathrm{f}$. . . share of tax. We're not people who get our hands $\mathrm{f}$. . . dirty. And I'm just being honest about that. (Birch, 2017, p. 84)

In COMFORT, A's challenging questions to a social worker who is attempting to help summarizes these female criminals' high sense of frustration and lack of faith in the justice system:

In what way will you be helping us? Will you be moving with us and help her sleep at night? Will you stand in front of windows when bricks come in? Will you give all your time to my other kids 'cos she requires everything I got? Will you be paying our bills? Can you get her off drugs? Can you get her to eat? Can you stop her from vomiting? Can you stop them from coming into my house and dragging her out by her hair? What Actual Tangible support will you be giving us? (Birch, 2017, p. 169)

When the social worker replies, "I just wanted you to know that I was Fighting for you ... I think Together we could," unfortunate A asks her to "get off [her] doorstep" (Birch, 2017, p. 169). In SOMEONE, B, who is badly bruised, refuses to comment on anything because she is scared that, like last time, even if A is bailed out, "he'll get out and will get [her] and if you don't get him, he'll get me. And then one day he'll kill me. And then you'll lock him up. For a bit. And then that'll be the end of it. That'll be how it ends" (Birch, 2017, p. 195). Even if the social worker wants to help, sometimes she cannot, simply because she does not have the realistic means to make a difference. In 45, B summarizes her frustration in not being able to help many of the female prisoners:

My objection to it is not administrative. I'm not Raising this because it is administratively complicated for me . . . because I fear the repercussions on my record if I don't hit all my targets-my bringing this to your attention was because I cannot stand in front of forty-five different women and get a clear picture of their mental wellbeing and their likelihood to commit an act of self-harm-particularly given the pool of women we're talking about have a History of self-harm and suicidal thoughtsI cannot Do that giving, what, two minutes per woman? (Birch, 2017, p. 239)

Unfortunately, hours later, in RESTAURANT, an inmate has committed suicide. The social worker, A, feels responsible since "she's been asking for help, I know that she has been asking for help and she's. I've been. I have been Meaning to get to her but because she is quiet I just haven't got there yet and. ...” (Birch, 2017, p. 247). In WRITE, B is very intimidated by an inmate: "she was threatening. I felt threatened. ... She stole Tampax. And nappies. And a 
baby grow and about eighty quids worth of makeup to flog . . . I I felt under threat .... I felt like we are in a dangerous situation ... unsafe," so she beat her up and sat on her neck (Birch, 2017, p. 9). These female prisoners' sense of fear and lack of faith in the system are unmistakable throughout the play.

Similarly, life outside prison is terrifying for these female prisoners as well. In GOODBYE, B is about to leave prison. She was born in prison because her mother, a drug addict and a repeat offender, was there. $\mathrm{C}$ and her mother left prison when $\mathrm{C}$ was one-year-old. $\mathrm{C}$ has returned to prison as a reoffender - a drug seller and a prostitute - three times. She feels prison is home to her. Every time she leaves prison, there is "a bit of [her] just saying, you'll [be] back. You know? . . . It's like, a revolving door, I guess. It feels really hard to get away from all the things that mean you just come back here" (Birch, 2017, p. 271). B adds that it is hard to have a job; that her mother will not meet with her, as a way to keep her away from prison; and that the "last three times, the first person who's come to pick [her]up or welcome [her] home is [her] dealer. So. That's just hard. . . . There's something About the Inevitability of it [reoffending] of Failing . . . Like it perfectly sums up Who I Am. And I think I sort of don't know what to do about that" (Birch, 2017, p. 273). In PIZZA, A's sister has been beaten up by her boyfriend: "He has pinned her up against the wall . . he'd pushed her face into her own vomit . . . he's kicked a baby out of her" (Birch, 2017, p. 55). By depicting the ugly, violent reality for these female prisoners on stage and the minimum difference offered by the people in charge, Birch is holding a mirror to society itself and emphasizing its responsibility to make a difference for these desperate women by thinking of possible ways to raise awareness of the possible biochemical role, which might make a difference.

\section{CONCLUSION}

Birch's high sense of social and human responsibility toward the female criminals' absurd reality is unmistakable throughout [BLANK]. Through the playwright's artistic talent, she communicates these characters' desperate cries for help using the theater of the absurd while employing in-yer-face theater to confront the audience - society — with the ugly reality of these women and their families. Through this confrontation, Birch is able to hold the audience by the scruff of their neck and force them to get the message by realizing the ugly cycle of these female characters' offending and reoffending and their responsibility in breaking this cycle. Birch implies the need to use different means other than the traditional forms of discipline for these female criminal behaviors, which heightens Birch's unique talent as a playwright. In the play, Birch suggests the possible biochemical role in helping these women and society - and not just the justice system - to break the ugly cycle of reoffending, which might help to improve these characters' difficult familial circumstances. This would be possible, Birch implies, if society were to end its stereotypical view of these women as pathetic criminals and give them mirrors as individuals who cannot grow out of repeated patterns of criminal behavior that are biologically beyond their human control. Birch challenges society's responsibility in contributing to these female criminals' reoffending and emphasizes society's role, not just that of the justice system, in helping them break the ugly cycle.

\section{REFERENCES}

Aberg, M. (2019). “[BLANK] Review-Alice Birch's Build-Your-Own-Play Experiment.” The Guardian. https://www.theguardian.com/stage/2019/oct/18/blank-review-alicebirch-donmar-warehouse-london 
Ambrogi, M. D. (2019, Nov 23). “Theater: Mirror Fragments.” The Lancet. (vol. 394)

Barbagli, R. (2015). Farewell to the World. Polity Press.

Bassuk, E., Schoonover, S., \& Gill, A. (1982). Lifelines: Clinical Perspectives on Suicide. Plenum Press.

Billington, M. (2018). “[Blank] Review-Alice Birch's Build-Your-Own-Play Experiment.” The Guardian.

Birch, A. (2017, June 4). “Alice Birch: 'I'm Interested in Whether Trauma Can Be Passed on through DNA."' Interview by Liz Hoggard. The Guardian.

Birch, A. (2018). [BLANK]. Bloomsbury Academic.

Camus, A. (1979). The Myth of Sisyphus: And Other Essays. Penguin.

Esslin, M. (2001). The Theater of the Absurd. Bloomsbury.

Evans, S. (1998). "Beyond the Mirror: A Group Analytic Exploration of Late Life and Depression." Aging \& Mental Health, (vol. 2, no. 2, pp. 94-99). https://doi.org/10.1080/13607869856786

Freud, S. (1958). The Standard Edition of the Complete Psychological Works of Sigmund Freud, translated and edited by James Strachey, (vol. 12), Hogarth Press.

Green, A. (1993, March). [The Dead Mother]. Psyche (Stuttgart), (vol. 47, no. 3, pp. 205-40).

Hinchliffe, A. P. (2019). The Absurd. Routledge, 2019. "The Incredible Symbolism of the Magnolia Tree." The Magnolia Company Blog, (2021, March 22) https://www.themagnoliacompany.com/blog/symbolism-of-the-magnolia-tree

"Introduction to Victimology." (2018). The American Society of Victimology, https://us.sagepub.com/sites/default/files/upm-assets/98849_book_item_98849.pdf

"In-yer-face theater." (1998) New Oxford Dictionary. In yer face theatre definitionhttps://jz.freetdmsmanual.online >

Jones, A. (2020). "Alice Birch On Her Impossible New Play, Succession and Adapting Sally Rooney for TV: 'I Feel Sick."'?

Kielholz, P. (1972). "Opening Address: Diagnostic Aspects in the Treatment of Depression." Depressive Illness: Diagnosis, Assessment, Treatment. University of Pennsylvania Press.

Kim, Y. K. (2018). editor. "Understanding Depression: Biomedical and Neurobiological Background (vol. 1), Springer.

Lacan, J. (1949/2006). “The Mirror Stage as Formative of the Function of the I." Écrits, edited by J. Lacan and J. A. Miller, W. W. Norton, pp. 75-81.

La Torre, M. A. (2005). Integrative perspectives: Self refection. Lesley U, PhD dissertation.

Levine, H. B. (2002). "Review Essay Self-Inquiry and The Relational Frame: A Historical Note". Psychoanalytic Dialogues, (V. 12, no. 2, pp. 305-315). Informa UK Limited, doi:10.1080/10481881209348669.

Masters, R. D., \& McGuire M. T. (1994). The Neurotransmitter Revolution. Southern Illinois University Press.

Melchior-Bonnet, S. (2001). The Mirror: A History, translated by Katherine H. Jewett. Routledge.

Pendergrast, M. (2003). Mirror: A History of the Human Love Affair with Reflection. Basic Books. 
Perina, K., ed. (2012). "Guilt”. Psychology Today Psychology Today, Sussex Publishers, LLC. https://www.psychologytoday.com/us/blog/fulfillment-any-age/201208/the-definitiveguide-guilt

Rebellato, D. (2017). "Of an Apocalyptic Tone Recently Adopted in Theatre: British Drama, Violence and Writing." Sillages Critiques, (no. 22). https://doi.org/10.4000/sillagescritiques.4798

Rocque, M., Welsh, B. C., \& Raine, A. (2012). Biosocial criminology and modern crime prevention. Journal of Criminal Justice, 40(4), 306-312. https://doi.org/10.1016/j.jcrimjus.2012.05.003

Saldanha, D., Kumar, N., Ryali, V. S. S. R., Srivastava, K., \& Pawar, A. A. (2009). Serum serotonin abnormality in depression. Medical Journal Armed Forces India, 65(2), 108-112. https://doi.org/10.1016/s0377-1237(09)80120-2

Schimelpfening, N. (2019, November 19). "How Genetics Can Factor into Depression." Verywell Mind. https://www.verywellmind.com/is-depression-genetic-1067317.

Shelly, C. (2020). "Capitalization in Fiction." Rabbit with a Red Pen. https://www.rabbitwitharedpen.com/blog/capitalization-in-fiction.

Siegel, A., \& Douard J. (2011). "Who's Flying the Plane: Serotonin Levels, Aggression and Free Will.” International Journal of Law and Psychiatry, (vol. 34, no. 1, pp. 20-29). https://doi.org/10.1016/j.ijlp.2010.11.004.

Sierz, A. (2001). In-Yer-Face Theater: British Drama Today. Faber \& Faber. "Types of Depression." Black Dog Institute, (2019). https://www.healthdirect.gov.au/depression

"What Lacan Means by The Mirror Stage English Literature Essay." (2018, November). ukessays.com, https://www.ukessays.com/essays/english-literature/what-lacan-meansby-the-mirror-stage-english-literature-essay.php?vref=1.

Wilson, L. C., \& Scarpa A. (2012). "Criminal Behavior". Journal of Contemporary Criminal Justice (vol. 28, no. 3, pp. 366-81). https://doi.org/10.1177/1043986212450232.

\section{AUTHOR'S BIO}

Madhawy Abdulaziz Almeshaal is an assistant professor at the English and Literature Department, College of Arts, King Saud University, Riyadh, Saudi Arabia. She teaches different courses in modern and contemporary English and American literature. She has received her BA degree form Marymount University, VA, USA, her MA degree from The American University, Washington D.C., and her Ph.D. degree from KSU, SA. Almeshaal's area of research interest has been mainly related to Modern \& Contemporary British and American drama and Theater Studies. 